\title{
Analisis Penerimaan Penggunaan E-Learning dengan Pendekatan Theory of Planned Behavior (TPB) pada Mahasiswa Akuntansi Universitas Jember
}

\author{
(Analysis The Acceptance and The Use of E-Learning with Theory of Planned Behavior \\ (TPB) Approach on Jember University Accounting Student)
}

\author{
Lifatin Sakdiyah", Rochman Effendi, Alwan Sri Kustono \\ Jurusan Akuntansi, Fakultas Ekonomi dan Bisnis, Universitas Jember (UNEJ) \\ Jln. Kalimantan 37, Jember 68121 \\ E-mail: lifatinsakdiyah@gmail.com
}

\begin{abstract}
Abstrak
Penelitian ini bertujuan untuk menganalisa penerimaan dan penggunaan e-learning dengan menggunakan pendekatan Theory of Planned Behavior (TPB) pada mahasiswa akuntansi Universitas Jember yang telah melakukan pemrograman tahun ajaran 2016/2017 semester genap. Penelitian ini diklasifikasikan sebagai explanatory research dengan pendekatan kuantitatif. Data yang diperoleh berupa data primer yang diperoleh secara langsung pada objek penelitian melalui menyampaikan kuesioner melalui personal chat baik melalui sosial media maupun e-mail. Kemudian, responden mengakses dan mengisi kuesioner secara online melalui link kuesioner yang telah diberikan. Metode analisis data yang digunakan dalam penelitian ini adalah Structural Equation Modeling (SEM) dengan menggunakan alat uji Smart PLS versi 3.2.3. Hasil analisis menunjukan bahwa dengan menggunakan metode TPB dapat diketahui hubungan signifikan antara niat perilaku terhadap perilaku penerimaan dan penggunaan e-learning serta hubungan tidak signifikan antara kontrol perilaku persepsian terhadap perilaku penerimaan dan penggunaan e-learning oleh mahasiswa Akuntansi Universitas Jember.
\end{abstract}

Kata Kunci: Sikap terhadap Perilaku, Norma Subyektif, Kontrol Perilaku Persepsian, Minat Perilaku, dan Perilaku Penerimaan Penggunaan E-Learning.

\begin{abstract}
This study aims to analyze the acceptance and use of e-learning by using Theory of Planned Behavior approach (TPB) in accounting students of University of Jember who have done programming of academic year 2016/2017 even semester. This research is classified as explanatory research with quantitative approach. The data obtained in the form of primary data obtained directly on the object of research through the submission of questionnaires through personal chat either through social media and e-mail. Then, the respondent access and fill the questionnaire online through the questionnaire link that has been given. Data analysis method used in this research is Structural Equation Modeling (SEM) by using SmartPLS version 3.2.3 test instrument. The result of analysis shows that by using TPB method can be known significant relationship between behavioral intention toward acceptance behavior and the use of e-learning as well as not significant relationship between perceptive behavior control toward acceptance behavior and the use of e-learning by accounting student of Jember University.
\end{abstract}

Keywords: Attitude toward Behavior, Subjective Norm, Perceived Behavior Control, Behavioral Intention, and Behavior The Acceptance and The Use of E-Learning.

\section{Pendahuluan}

Peranan teknologi informasi dalam kehidupan manusia akan terus berkembang sejalan dengan perkembangan ilmu pengetahuan dan teknologi. Kita tentunya dapat menyadari bagaimana perkembangan teknologi menciptakan efisiensi dalam berbagai bidang khususnya yang berkaitan dengan waktu, kecepatan, ketepatan informasi, tenaga, dan biaya. Perkembangan teknologi saat ini juga akan membantu dalam penggunaan sistem informasi yang tersedia. Peranan sistem informasi dalam suatu oraganisasi tentunya akan sangat membantu dalam bersaing dengan perusahaan yang lain atau bisa disebut keunggulan kompetitif.

Perkembangan teknologi akan mempengaruhi sistem informasi suatu organisasi tidak terkecuali universitas. Perguruan tinggi harus memiliki sistem informasi yang disiapkan untuk mendukung pengelolaan dan peningkatan mutu program akademik. Saat ini salah satu upaya peningkatan kualitas pendidikan dan kualitas sistem yang dilakukan universitas adalah dengan e-learning. E-learning merupakan singkatan dari Electronic Learning, merupakan cara baru dalam proses belajar mengajar yang menggunakan media elektronik khususnya internet sebagai sistem pembelajarannya.

E-learning merupakan salah satu upaya membangun pembelajaran yang memberikan kemudahan bagi mahasiswa untuk meningkatkan pengetahuan dan keterampilan berbasis online. E-learning akan dimanfaatkan atau tidak sangat bergantung pada cara pandang penggunanya. Umumnya suatu teknologi akan dipakai apabila teknologi tersebut merupakan suatu kebutuhan, terdapat fasilitas yang mendukung, serta ada dukungan dana dan dukungan dari pembuat kebijakan.

E-learning yang dibuat oleh Universitas Jember sampai saat ini tidak digunakan sebagai pengganti kelas (mahasiswa dan dosen bertemu secara langsung dan melakukan proses pembelajaran) namun e-learning ini digunakan sebagai

\footnotetext{
* Corresponding author
} 
sesuatu yang ditambahkan untuk melengkapi pengajaran dan interaksi antara dosen dan mahasiswa atau mahasiswa dengan mahasiswa lain yang dapat digunakan secara fleksibel melalui media internet.

Jogiyanto (2007:2) menjelaskan bahwa aspek perilaku (behavior) sangat banyak mempengaruhi keberhasilan atau kegagalan dari sistem informasi. Seringkali sistem informasi gagal dikarenakan saat digunakan sistem tidak diterima oleh penggunanya. Agar suatu sistem informasi nantinya diterima baik oleh penggunanya, maka perilaku penolakan perlu dirubah dan atau sistem perlu dipersiapkan agar perilaku pemerima mau menerima sistem tersebut. Untuk itu diperlukan penentuan penyebab perilaku penolakan atau penerimaan sistem. Salah satu penentu penerimaan atau penolakan sistem adalah kepercayaan.

Salah satu teori yang dapat digunakan untuk mengukur tingkat penerimaan penggunaan teknologi adalah Theory of Planned Behavior atau TPB. TPB merupakan perluasan dari Theory of Reasoned Action (TRA). TRA adalah teori tindakan beralasan dengan satu keyakinan bahwa reaksi dan persepsi seseorang terhadap suatu hal akan menentukan sikap dan perilaku orang tersebut. Dalam TRA minat seseorang terhadap perilaku dibentuk berdasarkan dua faktor yaitu sikap terhadap perilaku dan norma subyektif. Ajzen menambahkan konstruk yang belum ada di TRA. Konstruk ini disebut dengan presepsi kontrol prilaku (percaived behavioral control). Konstruk ini ditambahkan di TPB untuk mengontrol perilaku individual yang dibatasi oleh kekurangankekurangannya dan keterbatasan-keterbatasan dari kekurangan sumber-sumber daya yang digunakan untuk melakukan perilakunya (Chau and $\mathrm{Hu}, 2002$ dalam Jogiyanto, 2007).

Model TPB menjelaskan bahwa perilaku yang ditunjukkan seseorang timbul karena adanya minat untuk berperilaku. Dalam TPB minat perilaku (behavioral intention) ditentukan berdasarkan 3 faktor utama yaitu: sikap terhadap perilaku (attitude toward behavior), norma subyektif (subjective norm), dan presepsi kontrol perilaku (perceived behavior control).

Menurut Fishbein dan Ajzen (1980) sikap (attitude) merupakan keyakinan seseorang tentang hasilyang akan ditimbulkan dari keterlibatan dalam perilaku tertentu. Sedangkan sikap terhadap perilaku mengacu pada persepsi individu untuk melakukan suatu perilaku tertentu. Sedangkan menurut Jogiyanto $(2007: 38)$ sikap terhadap perilaku didefinisikan sebagai suatu evaluasi menyeluruh seseorang dalam melakukan suatu perilaku. Sikap terhadap perilaku ditentukan oleh kepercayaan-kepercayaan yang kuat tentang perilakunya yang disebut kepercayaan-kepercayaan perilaku (behavioral beliefs).

Norma subyektif adalah persepsi atau pandangan seseorang terhadap kepercayaan-kepercayaan orang lain yang akan mempengaruhi minat untuk melakukan atau tidak melakukan suatu perilaku (Jogiyanto, 2007:43). Norma subyektif ditentukan oleh kepercayaan-kepercayaan yang kuat tentang ekspetasi-ekspetasi normatif dari orang-orang lain dan motivasi untuk menyetujui ekspetasi-ekspetasi tersebut yang disebut kepercayaan-kepercayaan normatif (normative beliefs).
Ajzen (1991) menambahkan satu konstruk baru yaitu kontrol perilaku persepsian yang mana sebagian besar timbul karena kepercayaan bahwa individu tersebut mampu melakukan suatu perilaku serta kepercayaan faktor-faktor yang dirasakan akan memfasilitasi atau menghambat untuk melakukan suatu perilaku. Kontrol perilaku akan mencerminkan kepercayaan diri seseorang untuk melakukan perilaku tersebut. Presepsi kontrol perilaku ditentukan oleh kepercayaan-kepercayaan tentang keberadaan faktor-faktor yang akan memfasilitasi atau merintangi kinerja dari perilaku dan kekuatan persepsian dari faktor-faktor tersebut atau yang disebut kepercayaankepercayaan kontrol (control beliefs).

Minat perilaku dan perilaku adalah suatu hal yang berbeda. Minat perilaku menurut Jogiyanto (2007:116) adalah suatu keinginan (minat) seseorang untuk melakukan suatu perilaku tertentu. Seseorang akan melakukan suatu perilaku jika mempunyai keinginan atau minat untuk melakukannya. Sedangkan perilaku adalah tindakan nyata yang dilakukan seseorang.

Salah satu kelebihan TPB dibanding TRA adalah kemampuannya dalam menganalisis situasi dimana individu tidak sepenuhnya mempunyai kontrol sendiri terhadap perilakunya. TPB tidak secara langsung berhubungan dengan jumlah kontrol yang sebenarnya dimiliki seseorang, tetapi teori ini lebih mempertimbangkan pengaruh-pengaruh yang mungkin dari kontrol perilaku yang dipresepsikan dalam pencapaian tujuan-tujuan perilaku (Jogiyanto, 2007: 65).

Penelitian ini menggunakan TPB dalam menganalisis perilaku penerimaan dan penggunaan e-learning karena fokus utama penelitian ini adalah pada pemakaian fasilitas yang disediakan dalam e-learning Universitas Jember seperti fasilitas chating, penbuatan event, menyimpan file pribadi, serta mengecek daftar nama anggota forum. Pemakaian fasilitas yang ada pada e-learning Universitas Jember bersifat bebas, artinya pengguna berhak memakai atau tidak memakai fasilitas tersebut. Namun dalam kondisi tertentu pengguna tidak memiliki kontrol penuh untuk memutuskan memakai atau tidak memakai fasilitas tersebut. Kondisi yang mungkin terjadi memaksa pengguna tidak bisa memakai fasilitas tersebut karena ada faktor penghambat seperti kurangnya sumber daya pendukung. Oleh karena itu teori keperilakukan yang paling cocok untuk menganalisis penerimaan penggunaan e-learning Universitas Jember adalah Theory of Planned Behavior.

Penelitian ini dimaksudkan untuk menjelaskan hubungan kausal dan menguji keterkaitan antar beberapa variabel yaitu sikap terhadap perilaku, norma subyektif, kontrol perilaku persepsian, minat perilaku, dan perilaku penerimaan penggunaan e-learning dengan pendekatan TPB. Dengan penggunaan teori TPB diharapkan dapat memberikan gambaran apakah perilaku penerimaan penggunaan elearning dipengaruhi minat perilaku dan kontrol perilaku persepsian.

Ndubisi (2004) melakukan penelitian untuk menguji penerapan e-learning di Universitas Malaysia. Hasil penelitian menunjukkan bahwa sikap berpengaruh secara signifikan terhadap minat seseorang untuk melakukan suatu perilaku. Sikap dianggap memiliki pengaruh yang penting terhadap minat untuk mengadopsi e-learning. Temuan ini sangat relevan dengan teori yang dikemukakan Ajzen (1991) 
yang menyatakan bahwa sikap terhadap perilaku berpengaruh terhadap minat perilaku. Berdasarkan uraian diatas maka hipotesis yang akan diajukan dalam penelitian ini yaitu:

$\mathbf{H}_{1}$ : Sikap terhadap Perilaku berpengaruh secara positif terhadap Minat Perilaku

Penelitian yang dilakukan Ndubisi (2004) menunjukkan bahwa terdapat pengaruh positif dan signifikan yang dirasa norma subyektif terhadap minat perilaku melalui pengaruh pemimpin kursus komputer. Hal ini senada dengan pernyataan Ajzen (1991) bahwa norma subyektif berpengaruh terhadap minat perilaku. Berdasarkan uraian diatas maka hipotesis yang akan diajukan dalam penelitian ini yaitu:

$\mathbf{H}_{2}$ : Norma Subyektif berpengaruh secara positif terhadap Minat Perilaku.

Penelitian yang dilakukan Ndubisi (2004) menunjukkan bahwa terdapat pengaruh positif antara kontrol perilaku persepsian dengan minat perilaku. Ajzen (2002) mengatakan bahwa kontrol keperilakuan mempengaruhi minat didasarkan atas asumsi bahwa kontrol kepribadian yang dipersepsikan oleh individu akan memberikan implikasi motivasi pada orang tersebut. Semakin positif sikap seseorang terhadap perilaku dan norma subyektif, dan semakin besar kontrol presepsiannya, maka semakin kuat minat seseorang untuk memunculkan suatu perilaku. Berdasarkan uraian diatas maka hipotesis yang akan diajukan dalam penelitian ini yaitu:

$\mathbf{H}_{3}$ : Kontrol Perilaku Persepsian berpengaruh secara positif terhadap Minat Perilaku.

Penelitian yang dilakukan oleh Ndubisi (2004) menunjukkan bahwa perilaku seseorang dipengaruhi secara langsung dan signifikan melalui minat perilaku. Seseorang akan melakukan suatu perilaku jika mempunyai keinginan atau minat untuk melakukannya. Mahasiswa yang memiliki keinginan yang kuat untuk menggunakan e-learning akan cenderung untuk memanfaatkan fasilitas yang disediakan dalam e-learning. Berdasarkan uraian diatas maka hipotesis yang akan diajukan dalam penelitian ini yaitu:

Perilaku berpengaruh secara positif terhadap Perilaku.

Penelitian yang dilakukan oleh Baker \& White (2010) menunjukkan bahwa kontrol perilaku persepsian berpengaruh signifikan terhadap perilaku menggunakan SNS dengan tingkat 45\% varians. Menurut Ajzen (1991) kekuatan kontrol perilaku persepsian dalam menentukan perilaku secara langsung bergantung pada persepsi kontrol yang mencerminkan kontrol aktual. Berdasarkan uraian diatas maka hipotesis yang akan diajukan dalam penelitian ini yaitu:

H5 : Kontrol Perilaku Persepsian berpengaruh secara positif terhadap Perilaku.

Penelitian ini akan membahas secara terinci perilaku mahasiswa aktif dalam penerimaan penggunaan e-learning Universitas Jember. Sehingga dalam hal ini muncul pertanyaan penelitian, apakah sikap terhadap perilaku mempengaruhi minat perilaku mahasiswa akuntansi Universitas Jember dalam menggunakan e-learning, apakah norma subyektif mempengaruhi minat perilaku mahasiswa akuntansi Universitas Jember dalam menggunakan elearning, apakah kontrol perilaku presepsian mempengaruhi minat perilaku mahasiswa akuntansi Universitas Jember dalam menggunakan e-learning, apakah minat perilaku mempengaruhi perilaku mahasiswa akuntansi Universitas Jember dalam menggunakan e-learning, dan apakah kontrol perilaku persepsian mempengaruhi perilaku mahasiswa akuntansi Universitas Jember dalam menggunakan $e$ learning?

Berdasarkan rumusan masalah di atas, maka tujuan penelitian ini adalah untuk menguji apakah sikap terhadap perilaku mempengaruhi minat perilaku mahasiswa akuntansi Universitas Jember dalam menggunakan e-learning, untuk menguji apakah norma subyektif mempengaruhi minat perilaku mahasiswa akuntansi Universitas Jember dalam menggunakan e-learning, untuk menguji apakah kontrol perilaku presepsian mempengaruhi minat perilaku mahasiswa akuntansi Universitas Jember dalam menggunakan $e$ learning, untuk menguji apakah minat perilaku mempengaruhi perilaku mahasiswa akuntansi Universitas Jember dalam menggunakan e-learning, untuk menguji apakah kontrol perilaku persepsian mempengaruhi perilaku mahasiswa akuntansi Universitas Jember dalam menggunakan e-learning.

\section{Rancangan Penelitian}

\section{Metode}

Berdasarkan latar belakang masalah dan rumusan masalah yang ada, karakteristik permasalahan yang diteliti dalam penelitian ini dapat diklasifikasikan sebagai explanatory research dengan pendekatan kuantitatif. Explanatory research yaitu penelitian yang menjelaskan hubungan kausal dan menguji keterkaitan antar beberapa variabel melalui pengujian atau penelitian penjelasan (Singarimbun dan Efendi, 2003). Sedangkan paradigma penelitian kuantitatif merupakan penelitian yang menekankan pada pemahaman mengenai masalah-masalah dalam kehidupan sosial berdasarkan kondisi realitas atau natural setting yang holistis, kompleks dan rinci. Penelitian ini menguji penerimaan penggunaan e-learning.

\section{Jenis dan Sumber Data}

Data yang digunakan dalam penelitian ini adalah data primer. Metode pengumpulan data primer dilakukan melalui kuesioner online dimana responden dapat mengakses dan mengisi kuesioner secara online melalui link kuesioner yang telah diberikan.

\section{Populasi dan Sampel}

Berdasarkan tujuan penelitian, populasi penelitian adalah mahasiswa aktif program studi S1 Akuntansi Universitas Jember yang berjumlah 818 orang. Metode pemilihan sampel yang digunakan adalah metode pemilihan sampel secara tidak acak (non-randomly sampling method) berdasarkan kuota (quota sampling). Ukuran sampel yang sesuai dengan SEM untuk dilakukan penelitian adalah sekitar 100-200 responden. Dalam penelitian ini, peneliti akan mengambil 100 sampel dengan penentuan jumlah sampel ditentukan secara proporsional. 
Tabel 1. Daftar Jumlah Sampel Proporsional per Tahun Angkatan

\begin{tabular}{ccc}
\hline No. & Tahun Angkatan & Jumlah \\
\hline 1 & 2016 & 20 \\
2 & 2015 & 19 \\
3 & 2014 & 28 \\
4 & 2013 & 17 \\
5 & 2012 & 8 \\
6 & 2011 & 5 \\
7 & 2010 & 3 \\
\hline & TOTAL & 100
\end{tabular}

Sumber : Data primer yang diolah, 2017

\section{Metode Analisis Data}

Metode analisis data yang digunakan dalam penelitian ini adalah Structural Equation Modeling (SEM). SEM merupakan teknik multivariate yang mengkombinasikan aspek regresi berganda dan analisis faktor untuk mengestimasi serangkaian hubungan ketergantungan secara simultan (Hair et al: 1998). Menurut Hussein (2015) para ahli metode penelitian mengelompokkan SEM menjadi dua pendekatan yaitu Covariance Based SEM (CBSEM) dan Variance Based SEM atau yang lebih dikenal dengan Partial Least Squares (PLS). Pada penelitian ini, penulis menggunakan alat statistik yaitu Smart Partial Least Square (SmartPLS) versi 3.2.3.

\section{Uji Kualitas Data}

\section{Evaluasi Outer Model}

Menurut Hussein (2015) analisa outer model digunakan untuk memastikan measurement yang digunakan layak untuk dijadikan pengukuran (valid dan reliabel). Analisa outer model merupakan model pengukuran yang menghubungkan indikator dengan variabel latennya. Untuk melakukan analisa ini dapat dilihat dari beberapa indikator:

\section{a) Convergent validity}

Merupakan pengukuran yang digunakan untuk mengetahui valid tidaknya indikator dalam mencerminkan variabel. Convergent validity dapat dilihat dari nilai outer loadings, dikatakan memiliki validitas tinggi apabila nilai yang diharapkan $>0,7$. Namun ada beberapa literatur yang memungkinkan menggunakan nilai toleransi sebesar 0,5 . Artinya nilai outer loadings $>0,5$ masih ditoleransi sebagai sebuah indikator yang valid.

Tabel 2. Hasil Pengujian Convergent Validity

\begin{tabular}{lccc}
\hline \multicolumn{1}{c}{ Variabel } & Indikator & $\begin{array}{c}\text { Outer } \\
\text { Loading }\end{array}$ & Keterangan \\
\hline Sikap terhadap & ATB1 & 0,823 & Valid \\
Perilaku & ATB2 & 0,849 & Valid \\
& ATB3 & 0,639 & Valid \\
& ATB4 & 0,852 & Valid \\
& ATB5 & 0,876 & Valid \\
& ATB6 & 0,661 & Valid \\
\hline Norma & SN1 & 0,766 & Valid \\
Subyektif & SN2 & 0,881 & Valid \\
& SN3 & 0,753 & Valid \\
& SN4 & 0,797 & Valid \\
\hline Kontrol & PBC1 & 0,816 & Valid
\end{tabular}

\begin{tabular}{|c|c|c|c|}
\hline Perilaku & $\mathrm{PBC} 2$ & 0,653 & Valid \\
\hline \multirow[t]{4}{*}{ Persepsian } & PBC3 & 0,768 & Valid \\
\hline & PBC4 & 0,762 & Valid \\
\hline & PBC5 & 0,285 & Tidak Valid \\
\hline & PBC6 & 0,807 & Valid \\
\hline \multirow[t]{5}{*}{ Minat Perilaku } & BI1 & 0,843 & Valid \\
\hline & $\mathrm{BI} 2$ & 0,579 & Valid \\
\hline & $\mathrm{BI} 3$ & 0,830 & Valid \\
\hline & BI4 & 0,685 & Valid \\
\hline & BI5 & 0,844 & Valid \\
\hline Perilaku & $\mathrm{B}$ & 1,000 & Valid \\
\hline
\end{tabular}

Sumber: Data primer yang diolah, 2017

Berdasarkan hasil pengujian convergent validity yang ditunjukkan Tabel 2 menunjukkan bahwa item PBC5 memiliki nilai faktor loading dibawah 0,5 . Oleh karena itu item tersebut harus dihapus dari model.

\section{b) Discriminant validity}

Discriminant validity merupakan pengukuran yang digunakan untuk mengetahui apakah konstruk memiliki diskriminan yang memadai yaitu dengan cara membandingkan nilai loading pada konstruk yang dituju harus lebih besar dibandingkan dengan nilai loading dengan konstruk yang lain. Nilai ini dapat dilihat dari nilai Average Variance Extracted (AVE). Indikator dapat dikatakan valid jika nilai $\mathrm{AVE}>0,5$.

Tabel 3. Hasil Deskriminan Validity

\begin{tabular}{lc}
\hline \multicolumn{1}{c}{ Variabel } & Nilai AVE \\
\hline Sikap terhadap Perilaku & 0,623 \\
Norma Subyektif & 0,641 \\
Kontrol Perilaku Persepsian & 0,594 \\
Minat Perilaku & 0,584 \\
Perilaku & 1,000 \\
\hline
\end{tabular}

Sumber: Data primer yang diolah, 2017

Tabel 3 menunjukkan bahwa nilai AVE $>0,5$ artinya semua variabel dalam model yang diestimasi memenuhi kriteria deskriminan validity. Model lain yang dapat dilakukan untuk menguji deskriminan validity adalah dengan melihat tabel cross loading sebagaimana Tabel 4 yang menunjukkan bahwa nilai loading dari masing-masing item terhadap konstruknya lebih besar dari nilai cross loadingnya.

Tabel 4. Hasil Cross Loading

\begin{tabular}{cccccc}
\hline $\begin{array}{c}\text { Indikator } \\
\text { Variabel }\end{array}$ & ATB & SN & PBC & BI & B \\
\hline ATB1 & 0,823 & 0,360 & 0,422 & 0,446 & 0,539 \\
ATB2 & 0,849 & 0,319 & 0,358 & 0,396 & 0,373 \\
ATB3 & 0,639 & 0,251 & 0,322 & 0,395 & 0,287 \\
ATB4 & 0,852 & 0,371 & 0,385 & 0,510 & 0,475 \\
ATB5 & 0,876 & 0,372 & 0,411 & 0,481 & 0,476 \\
ATB6 & 0,661 & 0,292 & 0,445 & 0,388 & 0,234 \\
SN1 & 0,414 & 0,766 & 0,261 & 0,338 & 0,254 \\
SN2 & 0,385 & 0,881 & 0,346 & 0,515 & 0,400 \\
SN3 & 0,345 & 0,753 & 0,245 & 0,283 & 0,211 \\
SN4 & 0,231 & 0,797 & 0,336 & 0,460 & 0,378 \\
PBC1 & 0,365 & 0,357 & 0,826 & 0,463 & 0,313 \\
PBC2 & 0,363 & 0,295 & 0,668 & 0,383 & 0,324 \\
PBC3 & 0,386 & 0,189 & 0,772 & 0,343 & 0,254 \\
PBC4 & 0,348 & 0,309 & 0,775 & 0,327 & 0,297 \\
PBC6 & 0,444 & 0,289 & 0,805 & 0,402 & 0,290
\end{tabular}




\begin{tabular}{cccccc} 
BI1 & 0,545 & 0,383 & 0,378 & 0,843 & 0,649 \\
BI2 & 0,367 & 0,081 & 0,456 & 0,580 & 0,348 \\
BI3 & 0,490 & 0,556 & 0,314 & 0,830 & 0,543 \\
BI4 & 0,267 & 0,392 & 0,425 & 0,686 & 0,372 \\
BI5 & 0,424 & 0,483 & 0,418 & 0,844 & 0,616 \\
B & 0,514 & 0,406 & 0,386 & 0,681 & 1 \\
\hline
\end{tabular}

Sumber: Data primer yang diolah, 2017

\section{c) Composite Reliability}

Merupakan pengukuran yang digunakan untuk melihat konsisten tidaknya indikator dalam mewakili variabel. Data yang memiliki nilai composite reliability $>0,6$ merupakan data yang reliabel.

Tabel 5. Hasil Composite Reliability

\begin{tabular}{lc}
\hline \multicolumn{1}{c}{ Variabel } & Composite Reliability \\
\hline Sikap terhadap Perilaku & 0,907 \\
Norma Subyektif & 0,877 \\
Kontrol Perilaku Persepsian & 0,879 \\
Minat Perilaku & 0,873 \\
Perilaku & 1,000 \\
\hline
\end{tabular}

Sumber: Data primer yang diolah, 2017

Selain itu dapat pula dilihat dari nilai cronbach's alpha. Apabila nilai cronbach's alpha $>0,6$ maka data dapat dikatakan reliabel.

Tabel 6. Hasil Cronbach's Alpha

\begin{tabular}{lc}
\hline \multicolumn{1}{c}{ Variabel } & Cronbach's Alpha \\
\hline Sikap terhadap Perilaku & 0,875 \\
Norma Subyektif & 0,821 \\
Kontrol Perilaku Persepsian & 0,828 \\
Minat Perilaku & 0,817 \\
Perilaku & 1,000 \\
\hline
\end{tabular}

Sumber: Data primer yang diolah, 2017

Hasil pengujian yang ditunjukkan Tabel 5 dan Tabel 6 menunjukkan nilai yang memuaskan artinya semua variabel memiliki reliabilitas yang baik.

Evaluasi Inner Model

Analisa inner model dilakukan untuk memastikan bahwa model struktural yang dibangun kuat dan akurat. Evaluasi inner model dilakukan melalui:

$$
R \text {-square }\left(\mathrm{R}^{2}\right)
$$

Nilai $\mathrm{R}^{2}$ digunakan untuk mengukur tingkat variasi perubahan variabel eksogen terhadap variabel endogen. Nilai koefisien determinasi adalah antara nol dan satu. Nilai $\mathrm{R}^{2}$ yang kecil berarti kemampuan variabel-variabel independen dalam menjelaskan variabel dependen amat terbatas. Nilai yang mendekati satu berarti variabel-variabel independen memberikan hampir semua informasi yang dibutuhkan untuk memberikan hampir semua informasi yang dibutuhkan untuk memprediksi variabel dependen (Ghozali, 2006).

Tabel 7. Nilai $R$-square

\begin{tabular}{cc}
\hline Variabel & $\mathbf{R}^{\mathbf{2}}$ \\
\hline Minat Perilaku & 0,450 \\
Perilaku & 0,467 \\
\hline
\end{tabular}

Sumber: Data primer yang diolah, 2017

\section{Q-square $\left(\mathrm{Q}^{2}\right)$}

Q-square bertujuan untuk mengukur seberapa baik nilai observasi yang dihasilkan oleh model dan juga estimasi parameternya (Ghozali, 2008). Nilai Q-square lebih besar dari 0 menunjukkan bahwa model memiliki nilai predictive relevance, sedangkan nilai $Q$-square kurang dari 0 menunjukkan bahwa model kurang memiliki predictive relevance. Nilai dari $\mathrm{Q}^{2}$ dapat dihitung dengan perhitungan berikut:

$\mathrm{Q}^{2}=1-\left(1-\mathrm{R} 1^{2}\right)\left(1-\mathrm{R} 2^{2}\right)$

Maka nilai dari $\mathrm{Q}^{2}$ adalah:

$\mathrm{Q}^{2}=1-\left(1-0,450^{2}\right)\left(1-467^{2}\right)=0,377$

c) Goodness of Fit (GoF)

Merupakan pengujian kecocokan antara hasil pengamatan dengan frekuensi yang diperoleh berdasarkan nilai harapannya. Cara melakukan uji GoF yaitu dengan melakukan perhitungan manual dengan rumus:

$$
\overline{\mathrm{GoF}}=\overline{\sqrt{A V E}} \mathrm{x} \mathrm{R}^{2}
$$

Berdasarkan rumus tersebut, dihasilkan nilai GoF sebesar 0,316. Menurut Tenenhau (2004) dalam Hussein (2015) nilai GoF small $=0,1$, GoF medium $=0,25$ dan GoF besar $=0,38$. Berdasarkan pengujian $\mathrm{R}^{2}, \mathrm{Q}^{2}$, dan $\mathrm{GoF}$ terlihat bahwa model yang dibentuk kuat sehingga pengujian hipotesis dapat dilakukan.

\section{Uji Hipotesis}

Pengujian hipotesis dilakukan dengan melihat nilai koefisien inner weight dari model struktural. Pengujian hipotesis pada penelitian ini dilakukan dengan melihat nilai t-hitung. Hasil output pengujian hipotesis ditunjukkan adalah sebagai berikut:

Tabel 8. Hasil Pengujian Hipotesis

\begin{tabular}{lcccc}
\hline $\begin{array}{c}\text { Pengaruh } \\
\text { Variabel }\end{array}$ & $\begin{array}{c}\text { Inner } \\
\text { Weight }\end{array}$ & t-tabel & t-stat & Keterangan \\
\hline ATB terhadap BI & 0,318 & 1,96 & 3,245 & Signifikan \\
\hline SN terhadap BI & 0,297 & 1,96 & 2,935 & Signifikan \\
\hline PBC terhadap BI & 0,234 & 1,96 & 2,199 & Signifikan \\
\hline BI terhadap B & 0,653 & 1,96 & 7,865 & Signifikan \\
\hline PBC terhadap B & 0,057 & 1,96 & 0,596 & $\begin{array}{c}\text { Tidak } \\
\text { Signifikan }\end{array}$ \\
\hline
\end{tabular}

Sumber: Data primer yang diolah, 2017

Berdasarkan Tabel 8 uji hipotesis menunjukkan hasil nilai koefisien regresi positif pada uji pengaruh ATB terhadap BI sebesar 0,318 dan nilai t-statistik 3,245> t-tabel 1,96. Dengan demikian, H1 diterima artinya variabel sikap terhadap perilaku (X1) terhadap variabel minat perilaku (Y1) berpengaruh secara positif dan signifikan.

Uji pengaruh norma subyektif terhadap minat perilaku menghasilkan nilai koefisien regresi positif yaitu sebesar 0,297 dan nilai t-statistik 2,935 > t-tabel 1,96. Dengan demikian, H2 diterima artinya variabel norma subyektif (X2) terhadap variabel minat perilaku (Y1) berpengaruh secara positif dan signifikan. 
Uji pengaruh kontrol perilaku persepsian terhadap minat perilaku menghasilkan nilai koefisien regresi positif yaitu sebesar 0,234 dan nilai t-statistik 2,199>t-tabel 1,96. Dengan demikian, H3 diterima artinya variabel kontrol perilaku persepsian (X3) terhadap variabel minat perilaku (Y1) berpengaruh secara positif dan signifikan.

Uji pengaruh minat perilaku terhadap perilaku menghasilkan nilai koefisien regresi positif yaitu sebesar 0,653 dan nilai tstatistik 7,865 > t-tabel 1,96. Dengan demikian, H4 diterima artinya variabel minat perilaku (Y1) terhadap variabel perilaku (Y2) berpengaruh secara positif dan signifikan.

Sedangkan uji pengaruh kontrol perilaku persepsian terhadap perilaku menghasilkan nilai koefisien regresi positif yaitu sebesar 0,653 dan nilai t-statistik 0,057> t-tabel 1,96. Dengan demikian, H5 diterima artinya variabel kontrol perilaku persepsian (X3) terhadap variabel perilaku (Y2) berpengaruh secara positif namun tidak signifikan.

\section{Hasil dan Pembahasan}

\section{Pengaruh Sikap terhadap Perilaku terhadap Minat Perilaku}

Hasil pengujian hipotesis menunjukkan sikap terhadap perilaku berpengaruh terhadap minat perilaku dengan arah positif. Dari hasil uji hipotesis pertama (H1) bahwa sikap terhadap perilaku berpengaruh terhadap minat perilaku dengan nilai koefisien regresi yaitu sebesar 0,318 . Hal ini menunjukkan bahwa untuk meningkatkan minat menggunakan e-learning maka harus meningkatkan perasaan positif pada penggunanya bahwa teknologi tersebut mudah digunakan dan bermanfaat. Semakin tinggi perasaan positif pengguna e-learning maka terdapat kecenderungan semakin meningkat minat mereka dalam menggunakan e-learning.

Sikap terhadap perilaku menggambarkan perasaan positif atau negatif individu jika harus melakukan suatu perilaku. Sikap terhadap perilaku memberi peranan besar dalam memprediksi perilaku yang akan ditunjukkan seseorang. Mahasiswa yang memiliki perasaan positif terhadap manfaat e-learning akan mendorong keinginan dalam dirinya untuk mempelajari dan menggunakan teknologi informasi tersebut.

Hasil penelitian ini sejalan dengan penelitian sebelumnya yang dilakukan oleh Ndubisi (2004) melakukan penelitian untuk menguji penerapan e-learning di Universitas Malaysia. Hasil penelitian menunjukkan bahwa sikap berpengaruh secara signifikan $(\mathrm{R} 2=0,42 ; \quad \mathrm{F}=68,02)$ terhadap minat seseorang untuk melakukan suatu perilaku, serta memprediksi $24 \%$ dari variasi dalam minat menggunakan $e$ learning. Sikap dianggap memiliki pengaruh yang penting terhadap minat untuk mengadopsi e-learning. Temuan ini sangat relevan dengan teori yang dikemukakan Ajzen (1991) yang menyatakan bahwa sikap terhadap perilaku berpengaruh terhadap minat perilaku. Jadi dapat disimpulkan bahwa sikap terhadap perilaku berpengaruh positif terhadap minat perilaku penerimaan penggunaan e-learning.

\section{Pengaruh Norma Subyektif terhadap Minat Perilaku}

Hasil pengujian hipotesis menunjukkan norma subyektif berpengaruh terhadap minat perilaku dengan arah positif. Dari hasil uji hipotesis kedua (H2) bahwa norma subyektif berpengaruh terhadap minat perilaku dengan nilai koefisien regresi yaitu sebesar 0,297. Hal ini menunjukkan bahwa untuk meningkatkan minat menggunakan e-learning maka harus meningkatkan dukungan yang positif. Pengetahuan dan pengalaman individu maupun orang lain akan membentuk niat menggunakan e-learning melalui dorongan dari orangorang yang berpengalaman menggunakan e-learning. Semakin besar dorongan yang diberikan maka terdapat kecenderungan semakin meningkat minat mereka dalam menggunakan e-learning.

Norma subyektif merupakan keyakinan individu mengenai harapan orang-orang yang dianggap penting untuk menampilkan perilaku tertentu atau tidak. Dukungan dari orang sekitar yang penting dan berpengaruh tentunya akan memberi peranan besar dalam memprediksi perilaku yang akan ditunjukkan seseorang. Mahasiswa yang memiliki mendapat dukungan dari orang sekitarnya akan mendorong keinginan dalam dirinya untuk mempelajari dan menggunakan teknologi informasi tersebut. Selain itu semakin besar harapan orang-orang yang dianggap penting terhadap individu mengenai suatu perilaku tertentu akan menimbulkan keinginan untuk memenuhi harapan tersebut atau melakukan perilaku yang diinginkan mereka. Semakin besar harapan orang-orang yang dianggap penting, maka semakin besar keinginan untuk memenuhi harapan tersebut sehingga semakin besar pula minat melakukan perilaku yang diharapkan.

Hasil penelitian ini sejalan dengan penelitian sebelumnya yang dilakukan oleh Ndubisi (2004) menunjukkan bahwa terdapat pengaruh positif dan signifikan yang dirasa norma subyektif terhadap minat perilaku melalui pengaruh pemimpin kursus komputer $(\mathrm{R} 2=0,10 ; \mathrm{F}=30,08)$. Hal ini senada dengan pernyataan Ajzen (1991) bahwa norma subyektif berpengaruh terhadap minat perilaku. Jadi dapat disimpulkan bahwa norma subyektif berpengaruh positif terhadap minat perilaku penerimaan penggunaan e-learning.

\section{Pengaruh Kontrol Perilaku Persepsian terhadap Minat Perilaku}

Hasil pengujian hipotesis menunjukkan kontrol perilaku persepsian berpengaruh terhadap penerapan minat perilaku dengan arah positif. Dari hasil uji hipotesis ketiga (H3) bahwa kontrol perilaku persepsian berpengaruh terhadap minat perilaku dengan nilai koefisien regresi yaitu sebesar 0,234. Hal ini menunjukkan bahwa semakin besar sumberdaya yang dimiliki dan semakin sedikit hambatan yang akan dihadapi maka dapat diduga semakin besar minat seseorang untuk berperilaku tertentu.

Kontrol perilaku persepsian sebagian besar timbul karena kepercayaan bahwa individu tersebut mampu melakukan suatu perilaku serta kepercayaan faktor-faktor yang dirasakan akan memfasilitasi atau menghambat untuk melakukan suatu perilaku. Kontrol perilaku persepsian akan merefleksikan pengalaman masa lalu dan juga mengantisipasi halanganhalangan yang ada. Mahasiswa yang memahami kegunaan dan kemudahan yang akan didapatkan dibanding hambatan dalam penggunaan e-learning maka dapat diduga akan terbentuk minat untuk menggunakan e-learning. Mahasiswa yang memiliki keahlian akademik yang baik akan terus mencari kemudahan dan tidak akan berhenti belajar, artinya mereka tetap memiliki motivasi dan keinginan untuk terus menggunakan e-learning. 
Hasil penelitian ini sejalan dengan penelitian sebelumnya yang dilakukan oleh Ndubisi (2004) menunjukkan bahwa terdapat pengaruh positif antara kontrol perilaku persepsian dengan minat perilaku $(\mathrm{R} 2=0,22 ; \mathrm{F}=15,21)$. Pengaruh positif ini timbul karena sumber daya untuk menggunakan $e$ learning telah terpenuhi dan adanya pengalaman terdahulu yang secara positif membentuk niat/minat menggunakan $e$ learning. Jadi dapat disimpulkan bahwa kontrol perilaku persepsian berpengaruh positif terhadap minat perilaku penerimaan penggunaan e-learning.

\section{Pengaruh Minat Perilaku terhadap Perilaku}

Hasil pengujian hipotesis menunjukkan minat perilaku berpengaruh terhadap penerapan perilaku dengan arah positif. Dari hasil uji hipotesis keempat (H4) minat perilaku berpengaruh terhadap perilaku dengan nilai koefisien regresi yaitu sebesar 0,653. Hal ini menunjukkan bahwa untuk memprediksi perilaku penerimaan penggunaan e-learning maka dapat dilihat dari minat perilakunya.

Perilaku yang ditunjukkan seseorang timbul karena adanya minat (intention) untuk berperilaku. Minat perilaku menurut Jogiyanto (2007) adalah suatu keinginan (minat) seseorang untuk melakukan suatu perilaku tertentu. Seseorang akan melakukan suatu perilaku jika mempunyai keinginan atau minat untuk melakukannya. Mahasiswa yang memiliki keinginan yang kuat untuk menggunakan e-learning akan cenderung untuk memanfaatkan fasilitas yang disediakan dalam e-learning.

Penelitian yang dilakukan oleh Ndubisi (2004) menunjukkan bahwa perilaku seseorang dipengaruhi secara langsung dan signifikan melalui minat perilaku $(\mathrm{R} 2=0,24 ; \mathrm{F}=30,11)$. Untuk meningkatkan minat dalam mengadopsi e-learning maka pihak sekolah/universitas di Malaysia harus membangun sikap positif pada siswa/mahasiswanya dengan meningkatkan manfaat, kemudahan, keamanan, serta kontrol perilaku. Meningkatnya minat menggunakan e-learning akan memberi pengaruh pada sikap individu dalam pengadopsian e-learning. Jadi dapat disimpulkan bahwa minat perilaku berpengaruh positif terhadap perilaku penerimaan penggunaan e-learning.

\section{Pengaruh Kontrol Perilaku Persepsian terhadap Perilaku}

Hasil pengujian hipotesis menunjukkan kontrol perilaku persepsian berpengaruh terhadap penerapan perilaku dengan arah positif. Dari hasil uji hipotesis kelima (H5) bahwa kontrol perilaku persepsian berpengaruh terhadap perilaku dengan nilai koefisien regresi yaitu sebesar 0,057. Hal ini menunjukkan bahwa apabila terdapat pertentangan antara minat individu dengan perilaku yang ditampilkan maka akan terjadi hubungan langsung antara kontrol perilaku dengan perilaku seseorang. Hal ini terjadi karena individu tersebut tidak memiliki kontrol sepenuhnya terhadap perilaku yang akan di tampilkan.

Kontrol perilaku persepsian sebagian besar timbul karena kepercayaan bahwa individu tersebut mampu melakukan suatu perilaku serta kepercayaan faktor-faktor yang dirasakan akan memfasilitasi atau menghambat untuk melakukan suatu perilaku. Mahasiswa yang memahami kegunaan dan kemudahan yang akan didapatkan dibanding hambatan dalam penggunaan e-learning maka dapat diduga akan terbentuk minat untuk menggunakan e-learning. Hasil penelitian ini sejalan dengan penelitian sebelumnya yang dilakukan oleh Baker \& White (2010) menunjukkan bahwa kontrol perilaku persepsian berpengaruh signifikan terhadap perilaku menggunakan SNS dengan tingkat $45 \%$ varians. Menurut Ajzen (1991) kekuatan kontrol perilaku persepsian dalam menentukan perilaku secara langsung bergantung pada persepsi kontrol yang mencerminkan kontrol aktual. Jadi dapat disimpulkan bahwa kontrol perilaku persepsian berpengaruh positif terhadap minat perilaku penerimaan penggunaan e-learning.

\section{Simpulan}

Berdasarkan hasil pengamatan, variabel sikap terhadap perilaku, norma subyektif, dan kontrol perilaku persepsian berpengaruh secara positif dan signifikan terhadap variabel minat perilaku. Variabel minat perilaku sebagai berpengaruh secara positif dan signifikan terhadap variabel perilaku dalam penerimaan penggunaan e-learning Universitas Jember. Variabel kontrol perilaku walaupun berpengaruh secara positif terhadap variabel perilaku namun tidak berpengaruh secara signifikan. Selain itu, tingkat penerimaan penggunaan e-learning Universitas Jember cukup diterima dan sudah digunakan dengan baik oleh mahasiswa. Hal ini dapat dilihat dari hasil sebaran data kuesioner yang menunjukkan sebagian besar mahasiswa sering menggunakan e-learning.

\section{Referensi}

Ajzen, I. \& Fishbein, M. 1980. Understanding Attitudes and Predicting Social Behavior. Prentice-Hall.

Ajzen, I. 1991. The theory of planned behavior, Organizational Behavior and Human Decision Processes. 50, 179-211.

Baker, Rosland K. and Katherine M. White. 2010. Predicting adolescent' use of social networking sites from an extended theory of planned behaviour perspective. Computers in Human Behavior, 26(6). pp. 1591-1597.

Barnett, William \& Adrien Presley. 2004. Theory of Planned Behavior Model in Electronic Learning: A Pilot Study. Volume V No. 1.

Ghozali, Imam. 2006. Aplikasi Analisis Multivariet dengan Program SPSS. Semarang:Badan Penerbit Universitas Diponegoro.

Hair, Jr. J.F., R. E. Anderson., R.L. Tatham., dan W.C. Black. 1998. Multivariate Data Analysis. Fifth Edition. Prentice-Hall, Inc., New Jersey 07458.

Hussein, Ananda S. 2015. Penelitian Bisnis dan Manajemen MenggunakanPartial Least Squares (PLS) dengan smartPLS 3.0. Fakultas Ekonomi dan Bisnis Universitas Brawijaya.

Jogiyanto. 2007. Sistem Informasi Keperilakuan. Edisi I. Yogyakarta: Andi.

Ndubisi, Nelson Oly. 2004. Factors influencing e-learning adoption intention: Examining the determinant structure of the decomposed theory of planned behaviour constructs. Universiti Malaysia Sabah F.T. Labuan Malaysia

Yogatama, Leo Agung Manggala. 2013. Analisis Pengaruh Attitude, Subjective Norm, dan Perceived Behavior Control terhadap Intensi Penggunaan Helm Saat Mengendarai Motor pada Remaja dan Dewasa Muda di Jakarta Selatan. Skripsi. Fakultas Psikologi. Universitas Atma Jaya. 